\title{
Is Parkinson's Disease a Vesicular Dopamine Storage Disorder? Evidence from a Study in Isolated Synaptic Vesicles of Human and Nonhuman Primate Striatum
}

\author{
Christian Pifl, ${ }^{1}$ Alex Rajput, ${ }^{2}$ Harald Reither, ${ }^{1}$ OJavier Blesa, ${ }^{3}$ Carmen Cavada, ${ }^{4}$ José A. Obeso, ${ }^{3}$ Ali H. Rajput, ${ }^{2}$ \\ and Oleh Hornykiewicz ${ }^{1}$ \\ ${ }^{1}$ Center for Brain Research, Medical University of Vienna, A-1090 Vienna, Austria, ${ }^{2}$ Movement Disorders Program Saskatchewan, Royal University \\ Hospital, University of Saskatchewan, Saskatoon, Saskatchewan, SK S7N OW8, Canada, ${ }^{3}$ Movement Disorders Group, Neurosciences Division, CIMA, and \\ Department of Neurology and Neurosurgery, Clinica Universidad de Navarra, E31008 Pamplona, Spain, and Departamento de Anatomía, Histología y \\ Neurociencia, Facultad de Medicina, Universidad Autónoma de Madrid, E28049 Madrid, Spain
}

The cause of degeneration of nigrostriatal dopamine (DA) neurons in idiopathic Parkinson's disease (PD) is still unknown. Intraneuronally, DA is largely confined to synaptic vesicles where it is protected from metabolic breakdown. In the cytoplasm, however, free DA can give rise to formation of cytotoxic free radicals. Normally, the concentration of cytoplasmic DA is kept at a minimum by continuous pumping activity of the vesicular monoamine transporter (VMAT)2. Defects in handling of cytosolic DA by VMAT2 increase levels of DA-generated oxy radicals ultimately resulting in degeneration of DAergic neurons. Here, we isolated for the first time, DA storage vesicles from the striatum of six autopsied brains of PD patients and four controls and measured several indices of vesicular DA storage mechanisms. We found that (1) vesicular uptake of DA and binding of the VMAT2-selective label $\left[{ }^{3} \mathrm{H}\right]$ dihydrotetrabenazine were profoundly reduced in PD by $87-90 \%$ and $71-80 \%$, respectively; (2) after correcting for DA nerve terminal loss, DA uptake per VMAT2 transport site was significantly reduced in PD caudate and putamen by 53 and 55\%, respectively; (3) the VMAT2 transport defect appeared specific for PD as it was not present in Macaca fascicularis (7 MPTP and 8 controls) with similar degree of MPTP-induced nigrostriatal neurodegeneration; and (4) DA efflux studies and measurements of acidification in the vesicular preparations suggest that the DA storage impairment was localized at the VMAT2 protein itself. We propose that this VMAT2 defect may be an early abnormality promoting mechanisms leading to nigrostriatal DA neuron death in PD.

Key words: dopamine; Parkinson's disease; striatum; synaptic vesicles; VMAT2

\section{Introduction}

Idiopathic Parkinson's disease is a chronic progressive neurodegenerative disease, biochemically characterized by loss of dopamine (DA) in brain regions innervated by the nigrostriatal pathway (Ehringer and Hornykiewicz, 1960; Hornykiewicz, 1998), linked to degeneration of the melanized, DA-containing pars compacta perikarya of the substantia nigra (Hassler, 1938; Greenfield and Bosanquet, 1953; Hornykiewicz, 1963; Gibb and Lees, 1991). The cause of degeneration of the brain DA neurons is still unknown. DA itself is easily (auto)oxidizable (Graham et al., 1978), promoting formation of reactive oxygen species (Hastings et al., 1996; Spencer et al., 1998), as well as normally metabolized intracellularly by monoamine oxidase to DOPAC, with reactive

Received Dec. 30, 2013; revised May 6, 2014; accepted May 7, 2014.

Author contributions: C.P., J.A.O., and 0.H. designed research; C.P., H.R., J.B., C.C., and 0.H. performed research; A.R. and A.H.R. contributed unpublished reagents/analytic tools; C.P. and 0.H. analyzed data; C.P., J.A.O., and 0.H. wrote the paper.

The authors declare no competing financial interests.

Correspondence should be addressed to Dr Christian Pifl, Center for Brain Research, Medical University of Vienna, Spitalgasse 4, A-1090 Vienna, Austria. E-mail: christian.pifl@meduniwien.ac.at.

DOI:10.1523/JNEUROSCI.5456-13.2014

Copyright $\odot 2014$ the authors $\quad 0270-6474 / 14 / 348210-09 \$ 15.00 / 0$ molecules as intermediates. In the last decades, involvement of defective vesicular brain DA transport as triggering the "toxicDA-cascade" has attracted special attention (Edwards, 1993; Miller et al., 1999; Uhl et al., 2000).

The vesicular monoamine transporter (VMAT) 2 is a protein located in the membrane of the synaptic vesicles where it serves two purposes: neurotransmission and neuroprotection (Guillot and Miller, 2009). In brain DA terminals, VMAT2 is responsible for the packaging of cytoplasmic DA into synaptic vesicles, where the amine is held ready for vesicular neurotransmitter release. High intravesicular neurotransmitter concentrations are maintained by the transporter's continuous DA translocating activity driven by the $\mathrm{H}^{+}$ electrochemical force generated by a vesicular $\mathrm{H}^{+}$-ATPase (Moriyama and Futai, 1990). Simultaneously, VMAT2 serves a neuroprotective purpose by keeping the concentration of the free cytosolic DA at a minimum (Mosharov et al., 2003). Failure of vesicular DA sequestration results in reduced impulse-dependent DA release (Imperato and Di Chiara, 1984; Millar et al., 1985; Fon et al., 1997; Colliver et al., 2000) and accumulation of high free-cytosolic DA (Mosharov et al., 2003, 2009; Vergo et al., 2007), potentially resulting in production of DA-derived, cytotoxic reactive species (Caudle et al., 2008). 
Table 1. General characteristics of PD patients

\begin{tabular}{|c|c|c|c|c|c|c|}
\hline $\begin{array}{l}\text { Case } \\
\text { no. }\end{array}$ & $\begin{array}{l}\text { Age at } \\
\text { death/gender }\end{array}$ & $\begin{array}{l}\text { Clinical diagnosis } \\
\text { (duration of } \\
\text { disease, years) }\end{array}$ & PD medication & $\begin{array}{l}\text { Primary cause } \\
\text { of death }\end{array}$ & Brain pathology & $\begin{array}{l}\text { Postmortem } \\
\text { (death to autopsy) } \\
\text { interval, } h\end{array}$ \\
\hline 1 & $82 / F$ & iPD (8) & Levodopa/carbidopa & Respiratory failure & SN cell loss + LB & 8.5 \\
\hline 2 & $82 / F$ & iPD (18) & $\begin{array}{l}\text { Levodopa/benserazide, amantadine (none for } 1 \text { month } \\
\text { before death) }\end{array}$ & Respiratory failure & marked SN/LC cell loss + LB & 8 \\
\hline 3 & $66 / F$ & iPD (13) & Levodopa/carbidopa (last dose 2 weeks before death) & Colon cancer & mild to moderate SN/LC cell loss + LB & 6 \\
\hline 4 & $76 / \mathrm{M}$ & iPD (10) & Levodopa/benserazide (last dose just before death) & Cardiovascular failure & moderate to marked SN/LC cell loss + LB & 9 \\
\hline 5 & 84/M & ¡PD (16) & Levodopa/carbidopa (last dose $1 \mathrm{~h}$ before death) & Cardiac failure & marked SN/LC cell loss + LB & 5 \\
\hline 6 & $68 / M$ & iPD (23) & Levodopa/carbidopa, amantadine, bromocriptine & $\begin{array}{l}\text { Pulmonary embolism, } \\
\text { cardiac arrest }\end{array}$ & marked SN/LC cell loss + LB & 20 \\
\hline
\end{tabular}

iPD, Idiopathic PD; LB, Lewy body; SN, substantia nigra; LC, locus coeruleus.

In laboratory experiments, pharmacological VMAT2 blockade with tetrabenazine irreversibly decreased the animals' spontaneous activity and reduced the number of nigral DA neurons (Satou et al., 2001), and administration of reserpine induced signs of striatal oxidative stress (Fornstedt and Carlsson, 1989; Spina and Cohen, 1989; Bilska et al., 2007) and, in nigral cell cultures, DA-dependent oxidative cellular damage (Fuentes et al., 2007). In brains from PD patients, reduction of striatal dihydrotetrabenazine (DTBZ)-binding as a measure of VMAT2 levels, was less than the loss of striatal DA (Wilson et al., 1996), indicating a defective DA storage with fewer than normal DA molecules in each parkinsonian vesicle; this being concurrent with an earlier suggestion that "in PD a 'reserpine-like principle' might be active in the brain” (Hornykiewicz, 1964). Recently, a DA storage defect has been deduced from a study of catechol patterns of PD putamen (Goldstein et al., 2013).

Here, we for the first time provide direct evidence for, and describe the nature of a primary defect in DA transport function of the VMAT2 directly in synaptic vesicles isolated from the striatum of patients dying with PD. We suggest that this defect may be an early critical abnormality promoting degenerative death pathways underlying the progressive death of nigrostriatal DA neurons in this disorder.

\section{Materials and Methods}

Human brain tissue. Autopsied brains were obtained from six neuropathologically confirmed PD cases (66-84 years; 3 female, 3 male), and four control subjects ( $68-88$ years; 1 female, 3 male) without evidence in their records of any neurological or psychiatric disorder. Clinical information, drug history and major neuropathological findings of the patients with PD are shown in Table 1 . The mean age $( \pm$ SEM) of the control and PD patient groups $(79.0 \pm 4.4$ years, range: $68-88$ years and $76.3 \pm 3.2$ years, range: $66-84$ years, respectively) did not differ significantly nor did the mean postmortem time (= death to autopsy interval; controls; $12.8 \pm 1.9 \mathrm{~h}$, range: $7-15.5 \mathrm{~h}$; patients; $9.4 \pm 2.2 \mathrm{~h}$, range: $5-20$ h). At autopsy, brains were divided by a midsagittal section into two hemispheres, with one half-brain immediately frozen for neurochemistry, and the other half-brain preserved for neuropathological examination. For our study, the frozen half-brains were thawed to approximately $-10^{\circ} \mathrm{C}$ and cut by hand in the frontal plane in $\sim 3$ - to 5 -mm-thick slices, starting at the anterior border of the caudate head. For the preparation of synaptic vesicles tissue samples from slices of midcaudate (head) and midputamen slices were taken and stored at $-80^{\circ} \mathrm{C}$ until analyses.

MPTP monkey tissue. Putamen samples from male macaque monkeys (Macaca fascicularis) were used, derived from our recent study on MPTP-induced neurodegeneration (Blesa et al., 2012). MPTP (SigmaAldrich) was systemically administered using a dose regimen of 0.5 $\mathrm{mg} / \mathrm{kg}$ (i.v.) every 2 weeks until a stable parkinsonian state with persistent, clearly recognizable parkinsonian features was obtained. Animals were housed in an animal room under standard conditions and treated in accordance with the European and Spanish guidelines (86/609/EEC and
2003/65/EC European Council Directives; and the Spanish Government). The Bioethics Committees of the Universidad de Navarra and the Universidad Autónoma de Madrid approved the experiments. None of these monkeys received treatment with any antiparkinsonian drug or any other therapeutic intervention at any time during the study. The monkeys were killed at least 4 weeks after the last MPTP administration using deep anesthesia with pentobarbital, the brains removed and divided by a midsagittal section into two hemispheres, one of which was immediately frozen at $-80^{\circ} \mathrm{C}$ and kept frozen until vesicle preparation.

Preparation of synaptic vesicles. Samples of approximately $550-700 \mathrm{mg}$ of human striatal tissue (50-80 mg of monkey putamen) were homogenized in ice-cold $0.3 \mathrm{~m}$ sucrose containing $25 \mathrm{~mm}$ Tris, $\mathrm{pH} 7.4$, and $10 \mu \mathrm{M}$ pargyline, using seven up-down strokes in a glass Teflon Potter-type homogenizer and the whole further procedure was performed at $4^{\circ} \mathrm{C}$. For DA and homovanillic acid (HVA) determination (see below), a $20 \mu \mathrm{l}$ aliquot was diluted in $380 \mu \mathrm{l}$ of $0.1 \mathrm{~m}$ perchloric acid containing $0.4 \mathrm{~mm}$ sodium bisulfite and $8 \mathrm{ng}$ 3,4-dihydroxybenzylamine as internal standard. The sucrose-homogenate was centrifuged at $1000 \times g$ for $15 \mathrm{~min}$ and the supernatant recentrifuged at 20,000 $\times g$ for $30 \mathrm{~min}$. The resulting pellet ("P2") was subjected to osmotic shock by the addition of deionized $\mathrm{H}_{2} \mathrm{O}$ (caudate tissue was homogenized in $4 \mathrm{ml}$ using up-down strokes in the Potter, putamen tissue was resuspended in $1 \mathrm{ml} \mathrm{H}_{2} \mathrm{O}$, frozen for $\sim 15$ min, and after thawing, also homogenized in a total of $4 \mathrm{ml} \mathrm{H}_{2} \mathrm{O}$ ). The aqueous samples were centrifuged at 22,000 $\times \mathrm{g}$ for $15 \mathrm{~min}$ and osmolarity of the supernatant was readjusted by addition of $1.3 \mathrm{~m}$ potassium phosphate buffer, $\mathrm{pH} 7.4$, in $1 / 10$ the volume. The supernatant of the $20,000 \times g$ centrifugation (see above) was centrifuged at $100,000 \times g$ for $30 \mathrm{~min}$ and the resulting pellet was resuspended in the $\sim 3.7 \mathrm{ml}$ of the $22,000 \times g$ supernatant readjusted to $0.13 \mathrm{M}$ potassium phosphate, thus combining vesicles in the supernatant of the $\mathrm{P} 2$ pellet and in the hypoosmotically shocked $\mathrm{P} 2$ pellet. On each preparation from human tissue, vesicular uptake and efflux were done in parallel and one aliquot was kept for later $\left[{ }^{3} \mathrm{H}\right]$ DTBZ binding. For efflux $1.66 \mathrm{ml}$ of each preparation (obtained from 250-320 mg human tissue) was incubated in a total volume of $6 \mathrm{ml}$ assay buffer $\mathrm{KP}(0.13 \mathrm{M}$ potassium phosphate, $\mathrm{pH} 7.4)$ in the presence of $2 \mathrm{~mm} \mathrm{MgATP}$ and $0.1 \mu \mathrm{M}\left[{ }^{3} \mathrm{H}\right] \mathrm{DA}$ in a $30^{\circ} \mathrm{C}$ water bath for $4 \mathrm{~min}$ and then centrifuged at $4^{\circ} \mathrm{C}$ at $100,000 \times g$ for $45 \mathrm{~min}$. The rest of the preparation was split in half and similarly incubated and centrifuged in the absence of $\left[{ }^{3} \mathrm{H}\right] \mathrm{DA}$, obtaining one pellet for uptake and the other for proton gradient measurement.

Vesicular uptake. The pellet for uptake was resuspended in KP to obtain $4.75 \mathrm{ml}$ vesicle suspension. Uptake was performed in a total volume of $1.5 \mathrm{ml} \mathrm{KP}$ containing $2 \mathrm{~mm} \mathrm{MgATP}$ and various concentrations of $\left[{ }^{3} \mathrm{H}\right] \mathrm{DA}$ (New England Nuclear GmbH). Unspecific uptake was determined in the presence of $1 \mu \mathrm{M}$ reserpine. Transport was initiated by placing the tubes in a $30^{\circ} \mathrm{C}$ water bath and adding $0.5 \mathrm{ml}$ vesicle suspension (obtained from $\sim 20-25 \mathrm{mg}$ human and $6-8 \mathrm{mg}$ of monkey tissue) for the desired intervals of time. Uptake was terminated by the addition of 2.5 $\mathrm{ml}$ ice-cold $\mathrm{KP}$, immediate filtration under vacuum onto Whatman GF/B filter paper presoaked in $1 \%$ polyethylenimine, using a Brandel harvester. The filters were washed twice with additional $3 \mathrm{ml}$ of cold KP.

Vesicular efflux. The pellet of $\left[{ }^{3} \mathrm{H}\right] \mathrm{DA}$ loaded vesicles (see above) was resuspended in $7.75 \mathrm{ml}$ efflux buffer $(0.13 \mathrm{M}$ potassium phosphate, $20 \mathrm{~mm}$ 


\begin{tabular}{|c|c|c|}
\hline & Control & $\begin{array}{l}\text { Parkinson's } \\
\text { disease/MPTP }\end{array}$ \\
\hline \multicolumn{3}{|l|}{ Human putamen } \\
\hline $\mathrm{DA}(\mu \mathrm{g} / \mathrm{g})$ & $3.98 \pm 1.03$ & $0.14 \pm 0.07^{* * *}$ \\
\hline DOPAC $(\mu \mathrm{g} / \mathrm{g})$ & $0.285 \pm 0.110$ & $0.040 \pm 0.012^{*}$ \\
\hline DOPAC/DA (molar ratio) & $0.071 \pm 0.020$ & $0.393 \pm 0.070^{* *}$ \\
\hline HVA $(\mu \mathrm{g} / \mathrm{g})$ & $5.55 \pm 0.71$ & $2.45 \pm 0.94^{*}$ \\
\hline HVA/DA (molar ratio) & $1.52 \pm 0.46$ & $22.09 \pm 6.41^{*}$ \\
\hline \multicolumn{3}{|l|}{ Monkey putamen } \\
\hline $\mathrm{DA}(\mu \mathrm{g} / \mathrm{g})$ & $13.26 \pm 0.51$ & $0.46 \pm 0.08^{* * *}$ \\
\hline DOPAC $(\mu \mathrm{g} / \mathrm{g})$ & $0.951 \pm 0.060$ & $0.178 \pm 0.007^{* * *}$ \\
\hline DOPAC/DA (molar ratio) & $0.067 \pm 0.007$ & $0.460 \pm 0.103^{* * *}$ \\
\hline HVA $(\mu \mathrm{g} / \mathrm{g})$ & $20.19 \pm 0.46$ & $4.13 \pm 0.35^{* * *}$ \\
\hline HVA/DA (molar ratio) & $1.29 \pm 0.05$ & $9.08 \pm 1.50^{* * *}$ \\
\hline
\end{tabular}

${ }^{*} p<0.05,{ }^{* *} p<0.01,{ }^{* * *} p<0.002$ of PD or MPTP versus Control by Student's $t$ test. Values are given as mean \pm SEM.

MgATP, $10 \mu \mathrm{M}$ ascorbate, $10 \mu \mathrm{M}$ pargyline, $\mathrm{pH} 7.4)$ at $4^{\circ} \mathrm{C}$ in the cold room and kept on ice. Efflux was done parallel to vesicular uptake (see above) for each preparation. Aliquots of $500 \mu \mathrm{l}$ were incubated at $30^{\circ} \mathrm{C}$ for the times indicated; three samples in the presence of $0.1 \mathrm{mg} / \mathrm{L}$ nigericin. Efflux was terminated by filtration as in uptake experiments.

$\left[{ }^{3} \mathrm{H}\right] D T B Z$ binding. Vesicle suspension $(1.5 \mathrm{ml})$ put aside from vesicular uptake experiments for each preparation, were centrifuged at $100,000 \times g$ for $30 \mathrm{~min}$ at $4^{\circ} \mathrm{C}$ and the pellet was resuspended in $125 \mu \mathrm{l}$ of binding buffer SP (25 mm sodium phosphate, $\mathrm{pH}$ 7.7) and frozen at $-80^{\circ} \mathrm{C}$ until the binding experiment. This was performed in SP at a total volume of $75 \mu \mathrm{l}$ by incubating $25 \mu \mathrm{l}$ buffer, $25 \mu \mathrm{l} 12 \mathrm{~nm}( \pm)$-adihydrotetrabenazine $\left[2-{ }^{3} \mathrm{H}\right]$ (American Radiolabeled Chemicals), and $25 \mu \mathrm{l}$ thawed preparation for $90 \mathrm{~min}$ at $30^{\circ} \mathrm{C}$; unspecific binding was determined by the presence of $1 \mu \mathrm{M}$ tetrabenazine. Binding was terminated by the addition of $2.5 \mathrm{ml}$ ice-cold SP, immediate filtration under vacuum onto Whatman GF/B filter paper, using a Brandel harvester. The filters were washed twice with additional $3 \mathrm{ml}$ of cold SP.

Protein gradient measurement. Synaptic vesicles were prepared from $\sim 200-250 \mathrm{mg}$ putamen tissue, finally resuspended in $550 \mu \mathrm{l} \mathrm{KP}$ and half of it frozen for DA measurement after mixing with one-tenth of $1 \mathrm{M}$ perchloric acid containing $4 \mathrm{~mm}$ sodium bisulfite and $0.3 \mathrm{ng} \mathrm{3,4-}$ dihydroxybenzylamine as internal standard. Acidification of vesicles was measured in duplicates by ATP-dependent quenching of acridine orange fluorescence at $493 \mathrm{~nm}$ (excitation) and $530 \mathrm{~nm}$ (emission) in a Hitachi F-4500 fluorescence spectrophotometer (Nelson et al., 1988). Vesicular preparations ( $120 \mu \mathrm{l}$; or KP for subtraction of a blank trace) were mixed with $2.880 \mu \mathrm{l}$ reaction medium RM $(0.241 \mathrm{~m}$ sucrose, $5 \mathrm{~mm}$ Tricine$\mathrm{NaOH}, \mathrm{pH} 8.0,80 \mathrm{~mm} \mathrm{KCl}$ ) and incubated in a $3 \mathrm{ml}$ cuvette containing a small magnetic stirrer and tempered at $30^{\circ} \mathrm{C}$ for $2 \mathrm{~min}$. Then $6 \mu \mathrm{l} 1 \mathrm{~mm}$ acridine orange was added, recording of emission was started 2 min later. Fifteen microliters of $0.1 \mathrm{M} \mathrm{MgATP}$ was added $1 \mathrm{~min}$ and $3 \mu \mathrm{l}$ carbonyl cyanide p-trifluoromethoxyphenylhydrazone (FCCP; $1 \mathrm{~mm}$ in ethanol) 5 min after the start of recording.

Determination of DA and HVA. DA, serotonin (5-HT), DOPAC, and HVA were determined by means of high-performance liquid chromatography with electrochemical detection as described previously (Blesa et al., 2012).

Calculations and statistics. The DAergic contribution proper to striatal vesicular uptake per VMAT2 transport site (upt/site) in PD was calculated by $\mathrm{DA}_{\mathrm{PD}} /\left(\mathrm{DA}_{\mathrm{PD}}+5-\mathrm{HT}_{\mathrm{PD}}\right) \times(\text { upt } / \text { site })_{\mathrm{DA}, \mathrm{PD}}+5-\mathrm{HT}_{\mathrm{PD}} /$ $\left(\mathrm{DA}_{\mathrm{PD}}+5-\mathrm{HT}_{\mathrm{PD}}\right) \times(\text { upt/site })_{5-\mathrm{HT}, \mathrm{PD}}=(\mathrm{upt} / \text { site })_{\mathrm{PD}}$, with $\mathrm{DA}_{\mathrm{PD}}$ (putamen: Table 2; caudate: $1.00 \pm 0.49 \mu \mathrm{g} / \mathrm{g}$ ) and $5-\mathrm{HT}_{\mathrm{PD}}$ (putamen: $0.091 \pm$ 0.025 ; caudate: $0.062 \pm 0.015 \mu \mathrm{g} / \mathrm{g}$ ) being DA and 5-HT tissue levels in $\mathrm{PD}$ and the assumption of unchanged (Control) VMAT2 function (in contrast to the number of transport sites) in vesicles from 5-HTergic nerve terminals, (upt/site $)_{5-\mathrm{HT}, \mathrm{PD}}=(\text { upt/site })_{\text {Control }}$. Data are reported as mean \pm SE. Statistical analysis was done using two-sided unpaired Student's $t$ test.

\section{Results}

Characterization of vesicular DA uptake in human

postmortem tissue

Due to the limited amount of human striatal postmortem tissue available, we first optimized the protocol in preliminary experiments. In agreement with reports on vesicular transport in supernatants of a P2-pellets of a crude synaptosomal preparation (Philippu and Beyer, 1973; Seidler et al., 1977) and reports on vesicular transport in $\mathrm{H}_{2} \mathrm{O}$-lysates of $\mathrm{P} 2$-pellets (Whittaker et al., 1964; Erickson et al., 1990) we also found reserpine-sensitive and ATP-dependent DA uptake in both preparations (data not shown) and therefore combined both of them for maximal yield in all further experiments of this study.

Experiments on time-dependence of uptake showed linearity for up to 4 min of incubation (Fig. 1A) and a time interval of 4 min was used in further experiments. There was a linear tissuedependence up to $150 \mu$ g protein per tube (Fig. $1 B$ ); nevertheless, to rule out any effects of concentration, we used for vesicular preparations about the same amounts of tissue of each of the PD and control cases and performed the uptake, efflux, binding, and fluorometric assays with similar amounts of protein per tube (see below). Scatchard analysis of DA-dependence of uptake experiments (Fig. 1C) gave $\mathrm{K}_{\mathrm{M}}$ values in the range of $0.3 \mu \mathrm{M}$, and $0.1 \mu \mathrm{M}$ of DA was used in further uptake experiments. DA uptake by the vesicular preparation was reserpine-sensitive and ATPdependent and much higher in the putamen than in thalamic tissue with low monoaminergic innervation (Fig. 1D). Reserpine-sensitivity and ATP-dependence as well as the use of a sodium- and chloride-free potassium phosphate buffer rules out the possibility of any distorting contribution of the plasmalemmal sodium- and chloride-dependent DA transporter.

DA-uptake into synaptic vesicles from caudate of PD and controls We first determined specific vesicular DA uptake in the caudate. Compared with control, in caudate of PD patients vesicular DA uptake was profoundly reduced by $87 \%$ (Fig. $2 A$ ). Because this reduction may reflect both a reduced number of nerve endings and an impaired VMAT2 activity, we determined the overall number of VMAT2 sites in each vesicular preparation by binding of the VMAT2-selective label $\left[{ }^{3} \mathrm{H}\right] \mathrm{DTBZ}$ which was also highly reduced in $\mathrm{PD}$ by $71 \%$ (Fig. $2 B$ ). The calculated ratio of $\mathrm{DA}$ uptake to $\left[{ }^{3} \mathrm{H}\right] \mathrm{DTBZ}$ binding, reflecting number of transported DA molecules per unit time per VMAT2 transport site, was reduced in PD by $53 \%$ (Fig. 2C; $p=0.022$ by Student's $t$ test). Corrected for the VMAT2 in 5-HT terminals, the calculated (see Materials and Methods) reduction was by $56 \%$ of controls.

\section{$D A$-efflux from vesicles in the caudate of $P D$ and controls}

We loaded an aliquot of each of the vesicular preparations with $\left[{ }^{3} \mathrm{H}\right] \mathrm{DA}$, removed the extracellular tracer by centrifugation at $4^{\circ} \mathrm{C}$ and measured efflux of the stored DA by incubating the vesicles at $30^{\circ} \mathrm{C}$ for various time intervals and determined the remaining intravesicular tritium. There was a time-dependent reduction of vesicular tritium, in absolute amounts at a lower level in PD (Fig. 2D); however, efflux was clearly not faster but slightly attenuated compared with controls if data were normalized to the initial levels of loaded tritium ( $p=0.039$ at $10 \mathrm{~min}$ by Student's $t$ test; Fig. 2E). Quantitatively, efflux rates were considerably lower than uptake rates (controls: $0.3 \mathrm{pmol} / \mathrm{min}$ vs 3.3 $\mathrm{pmol} / \mathrm{min}$; PD: $0.1 \mathrm{pmol} / \mathrm{min}$ vs $0.4 \mathrm{pmol} / \mathrm{min}$ ); therefore the $20 \%$ reduction of efflux in PD cannot be construed as significantly compensating the effect of reduced uptake on cytosolic DA concentrations. To examine the background of not releasable DA 

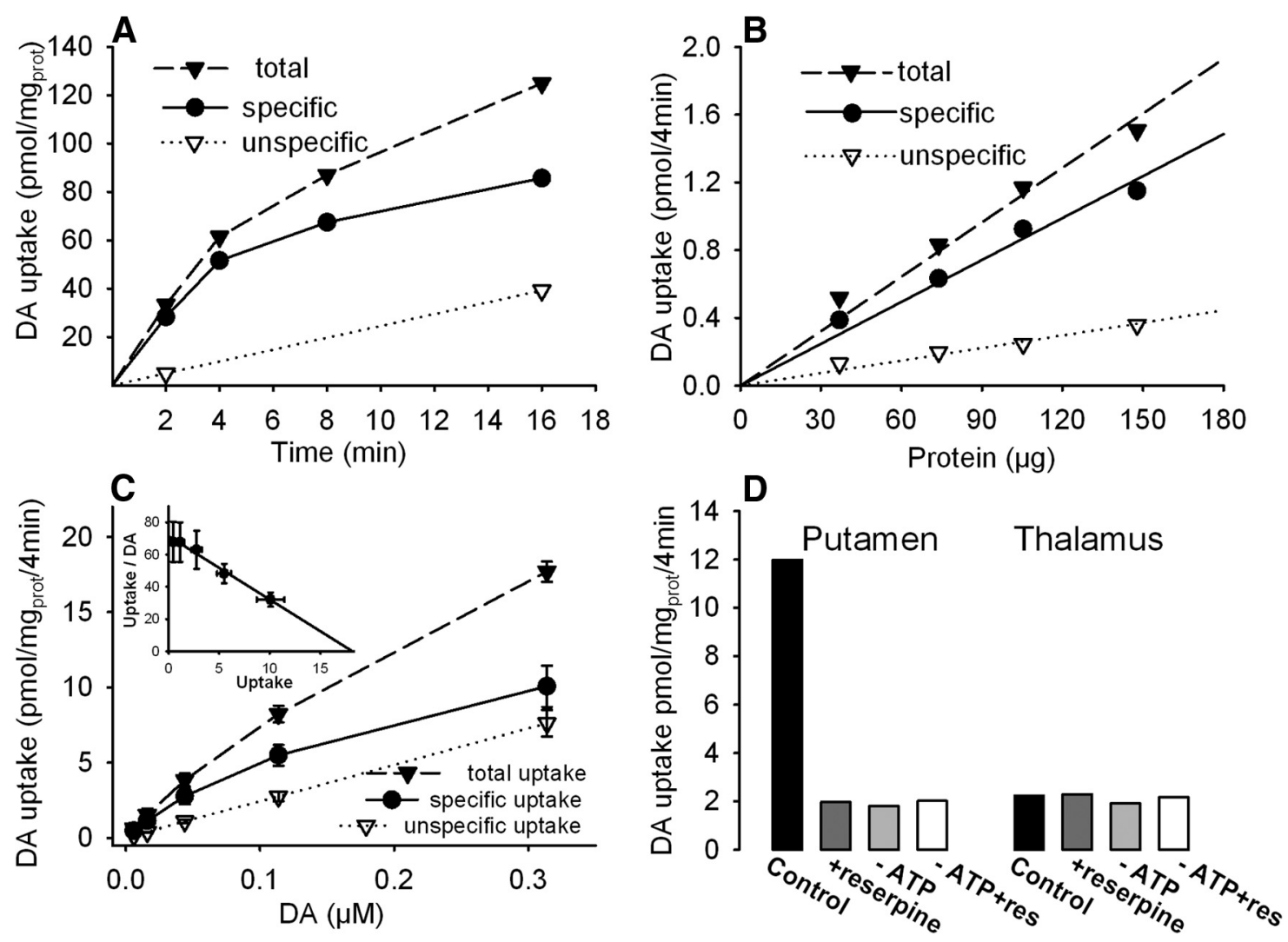

Figure 1. DA uptake by synaptic vesicles prepared from human control striatal tissue. $A$, Time-dependence of DA uptake. Synaptic vesicle preparations from striatum were incubated in the absence or presence of $1 \mu \mathrm{m}$ reserpine with $0.3 \mu \mathrm{m}\left[{ }^{3} \mathrm{H}\right] \mathrm{DA}$ at $30^{\circ} \mathrm{C}$ for the times indicated. Specific uptake (filled symbols, solid line) was calculated by subtraction of unspecific from total uptake. Data shown are mean values of triplicates. $\boldsymbol{B}$, Protein-dependence of $D A$ uptake. Synaptic vesicle preparations from caudate/putamen at the protein amounts indicated were incubated with $0.1 \mu \mathrm{m}$ $\left[{ }^{3} \mathrm{H}\right] \mathrm{DA}$ at $30^{\circ} \mathrm{C}$ for $4 \mathrm{~min}$ in the absence or presence of $1 \mu \mathrm{m}$ reserpine. Data shown are mean values of triplicates. $\mathrm{C}$, Concentration-dependence of DA uptake. Synaptic vesicle preparations from striatum were incubated with $\left[{ }^{3} \mathrm{H}\right] \mathrm{DA}$ at the concentration indicated at $30^{\circ} \mathrm{C}$ for $4 \mathrm{~min}$ in the absence or presence of $1 \mu \mathrm{m}$ reserpine. Inset, Scatchard transformation of specific uptake. Data shown are mean values \pm SE of three independent experiments, each done in triplicates. $D$, ATP-dependence and striatal specifity of DA uptake. Synaptic vesicle preparations (33-35 $\mu \mathrm{g}$ protein) of putamen or thalamus were incubated with $0.3 \mu \mathrm{m}\left[{ }^{3} \mathrm{H}\right] \mathrm{DA}$ at $30^{\circ} \mathrm{C}$ for $4 \mathrm{~min}$ in the absence or presence of $1 \mu \mathrm{m}$ reserpine and $2 \mathrm{~mm} \mathrm{MgATP}$. Data shown are mean values of triplicate.

in the preparation and in search for a difference between controls and PD, we measured efflux for $2 \mathrm{~min}$ in the presence of the ionophore nigericin at a threshold concentration based on preliminary experiments on control tissue. In both, control and PD preparation nigericin reduced the intravesicular tritium levels to approximately the levels obtained after 10-30 min of efflux and the values in the presence of nigericin were significantly higher in PD than in control samples if normalized to initial levels of loaded tritium ( $p=0.030$ by Student's $t$ test;Fig. $2 D, E)$.

DA-uptake and efflux in the putamen of PD and controls

In a second, independent experiment we performed the same experiments in tissue from the putamen. There was again a marked decrease of absolute DA uptake (Fig. $3 A$ ) and $\left[{ }^{3} \mathrm{H}\right] \mathrm{DTBZ}$ binding (Fig. $3 B$ ) in PD putamen by 90 or $82 \%$, respectively, with the uptake rate per transport site showing a significant reduction by $55 \%$ (Fig. $3 C ; p=0.032$ by Student's $t$ test); corrected for the VMAT2 in 5-HT terminals (for calculations, see Materials and Methods) the reduction per DA transport site amounted to $90 \%$. Although in controls there were lower uptake rates per transport site in putamen than in caudate $(0.97 \pm 0.17$ vs $2.81 \pm 0.54, p=$ 0.017 by Student's $t$ test), a slightly different protocol of preparation (freezing of the P2-pellet of putamen before lysis for obtaining a higher yield of vesicles) makes a direct comparison of the data questionable. Findings in efflux experiments in controls and PD were similar to caudate and did not reveal impaired retention of DA in vesicles of PD putamen (Fig. $3 D, E$ ).
DA-uptake in the putamen of MPTP monkeys and controls

Obviously, the main difference between control and PD striatal tissue is the severe reduction of DAergic nerve terminals in PD as reflected by the $\sim 90 \%$ reduction of absolute values of vesicular DA uptake. Theoretically, the reduced VMAT2 uptake rate per transport site in PD might be due to the specific situation of "diluted" vesicular transporter sites in the denervated striatal tissue. Therefore, we compared our results in PD with results obtained in vesicular preparations from tissue of MPTP-treated monkeys with a comparable degree of DAergic denervation (putamen DA in percentage of control: $3.56 \pm 1.85, \mathrm{PD} ; 3.45 \pm 0.63$, MPTP monkeys). MPTP administration resulted in a $92 \%$ reduction of vesicular DA uptake in preparations of monkey putamen (Fig. 4A); however if the reduction of $\left[{ }^{3} \mathrm{H}\right] \mathrm{DTBZ}$ binding (Fig. $4 B$ ) sites was taken into account, the uptake rate per monoamine transport site was unchanged compared with controls (Fig. 4C).

$D A$ and metabolites in the putamen of PD, MPTP-monkeys and in vesicles of $P D$ and controls

Increased HVA/DA and DOPAC/DA ratios in PD striatum can be due to either a compensatory increase of DA turnover or an impaired DA sequestration in vesicles. We therefore measured DA and HVA in the same putamen samples from which vesicles were prepared by precipitating an aliquot from the initial sucrose homogenates with perchloric acid (Table 2). DA levels were reduced by $96 \%$ in humans with PD and by $97 \%$ in monkeys with MPTP-parkinsonism, with HVA and DOPAC reductions of 56 

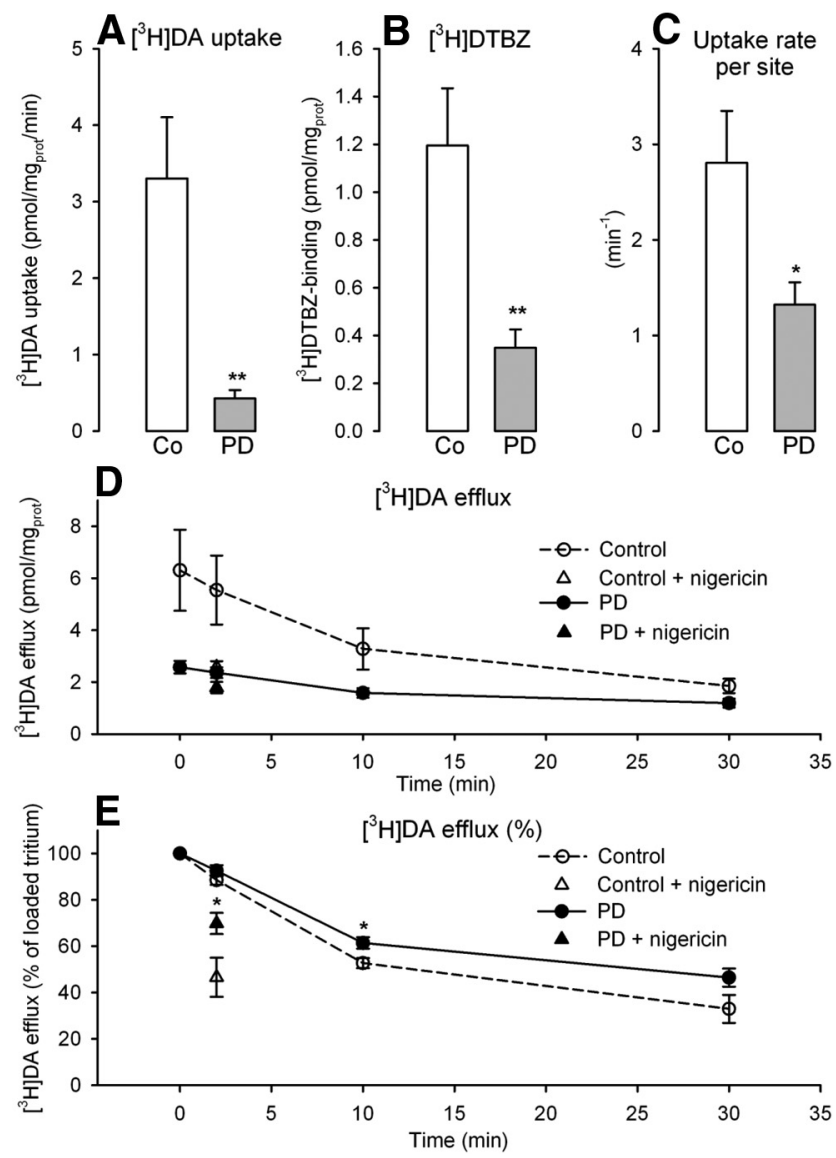

Figure 2. Synaptic vesicles prepared from caudate of patients with PD and controls. A, Specific DA uptake. Synaptic vesicle preparations ( $16 \pm 4$ and $19 \pm 3 \mu \mathrm{g}$ protein for controls and $P D$, respectively) were incubated in the absence or presence of $1 \mu \mathrm{m}$ reserpine with $0.1 \mu \mathrm{m}$ $\left[{ }^{3} \mathrm{H}\right] \mathrm{DA}$ at $30^{\circ} \mathrm{C}$ for $4 \mathrm{~min} ;{ }^{* *} p<0.002$ specific uptake in PD versus control by Student's $t$ test. $\boldsymbol{B}$, DTBZ-binding. Synaptic vesicle preparations ( $3.7 \pm 1.6$ and $4.2 \pm 0.7 \mu \mathrm{g}$ protein for controls and PD, respectively) were incubated in the absence or presence of $1 \mu \mathrm{m}$ tetrabenazine with 4 $\mathrm{nm}\left[{ }^{3} \mathrm{H}\right] \mathrm{DTBZ}$ at $30^{\circ} \mathrm{C}$ for $90 \mathrm{~min}$; ${ }^{* *} p<0.004$ specific binding in PD versus control by Student's $t$ test. C, Uptake per DTBZ-binding site. For each synaptic vesicle preparation specific DA uptake was divided by specific DTBZ-binding; ${ }^{*} p<0.03$ uptake rate per transport site in PD versus control by Student's $t$ test. $D, D A$ efflux. Synaptic vesicle preparations were loaded with DA by incubation with $0.1 \mu \mathrm{m}\left[{ }^{3} \mathrm{H}\right] \mathrm{DA}$ at $30^{\circ} \mathrm{C}$ for $4 \mathrm{~min}$, centrifuged and the pellet resuspended at $4^{\circ} \mathrm{C}$ and finally incubated at $30^{\circ} \mathrm{C}$ for 2 (in the presence and absence of $0.1 \mathrm{mg} / \mathrm{L}$ nigericin), 10 , and $30 \mathrm{~min}$. DA retained was determined by filtration. $\boldsymbol{E}$, DA efflux presented in percentage of loaded DA. ${ }^{*} p<0.05$ efflux in PD versus control by Student's $t$ test. Data shown are mean values \pm SE of four controls and six PD cases, each done in triplicate.

and $86 \%$ in PD, and 80 and $81 \%$ in MPTP monkeys, respectively, resulting in significantly increased HVA/DA and DOPAC/DA ratios in both PD and MPTP with the ratios calculated from the final metabolite HVA being more than twofold higher in PD than in MPTP primate (Table 2). To estimate a potential interference by the endogenous DA retained in our vesicular preparations with the in vitro DA uptake, we determined the residual DA levels in vesicular fractions prepared from putamen. Vesicular DA levels were $96.1 \pm$ $7.8 \mathrm{fmol} / \mathrm{mg}_{\text {prot }}(n=4)$ in controls and $8.7 \pm 4.8(n=5)$ in PD. Relative to the number of $\left[{ }^{3} \mathrm{H}\right] \mathrm{DTBZ}$ binding sites, residual DA levels per VMAT2 binding site $\left(\mathrm{pmol}_{\mathrm{DA}} / \mathrm{pmol}_{\mathrm{DTBZ}}\right)$ were clearly not increased in PD, with $0.047 \pm 0.010(n=4)$ in controls and $0.021 \pm$ 0.009 in $\mathrm{PD}$ ( $n=5$; difference not significant).

Proton uptake into vesicles from putamen of PD and controls Because monoamine uptake into vesicles is driven by the proton gradient at the vesicular membrane, we determined fluorescence

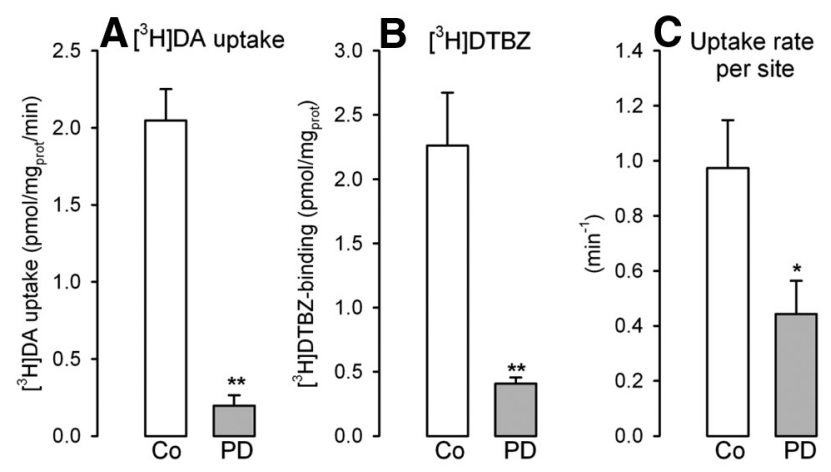

$\left[{ }^{3} \mathrm{H}\right] \mathrm{DA}$ efflux
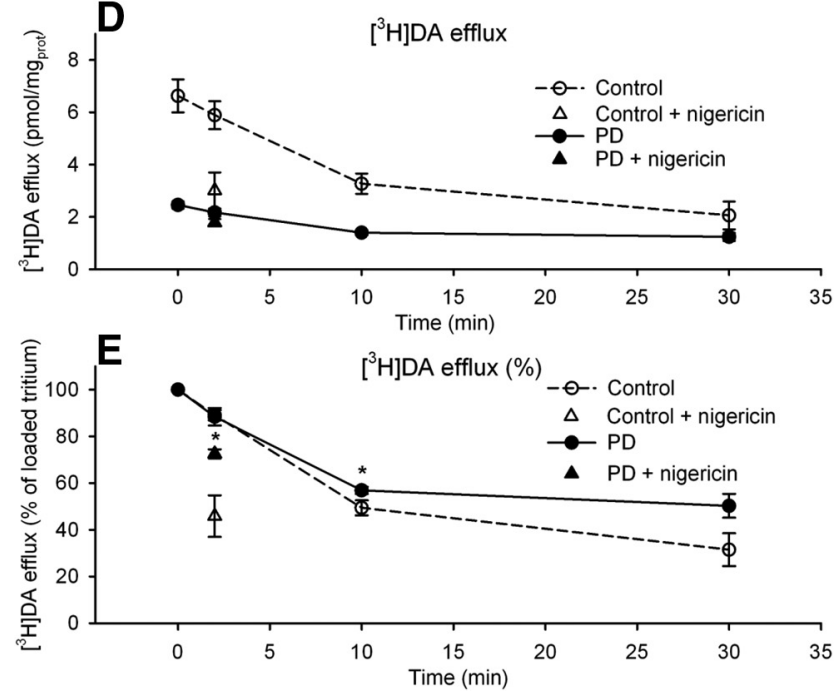

Figure 3. Synaptic vesicles prepared from putamen of patients with PD and controls. $\boldsymbol{A}$, Specific DA uptake. Synaptic vesicle preparations ( $28 \pm 5$ and $31 \pm 6 \mu$ g protein for controls and PD, respectively) were incubated in the absence or presence of $1 \mu \mathrm{m}$ reserpine with $0.1 \mu \mathrm{m}\left[{ }^{3} \mathrm{H}\right] \mathrm{DA}$ at $30^{\circ} \mathrm{C}$ for $4 \mathrm{~min} ;{ }^{* *} p<0.00001$ specific uptake in PD versus control by Student's $t$ test. $\boldsymbol{B}$, DTBZ-binding. Synaptic vesicle preparations $(6.5 \pm 0.71$ and $8.0 \pm 1.3 \mu \mathrm{g}$ protein for controls and $\mathrm{PD}$, respectively) were incubated in the absence or presence of $1 \mu \mathrm{m}$ tetrabenazine with $4 \mathrm{~nm}\left[{ }^{3} \mathrm{H}\right] \mathrm{DTBZ}$ at $30^{\circ} \mathrm{C}$ for $90 \mathrm{~min} ;{ }^{* *} p<0.0005$ specific binding in PD versus control by Student's $t$ test. C, Uptake per DTBZ-binding site. For each synaptic vesicle preparation specific DA uptake was divided by specific DTBZbinding; ${ }^{* *} p<0.05$ uptake rate per transport site in PD versus control by Student's $t$ test. $D$, DA efflux. Synaptic vesicle preparations were loaded with DA by incubation with $0.1 \mu \mathrm{M}$ $\left[{ }^{3} \mathrm{H}\right] \mathrm{DA}$ at $30^{\circ} \mathrm{C}$ for $4 \mathrm{~min}$, centrifuged and the pellet resuspended at $4^{\circ} \mathrm{C}$ and finally incubated at $30^{\circ} \mathrm{C}$ for 2 (in the presence and absence of $0.1 \mathrm{mg} / \mathrm{L}$ nigericin), 10 , and 30 $\min$. DA retained was determined by filtration. $E, D A$ efflux presented in percentage of loaded DA. ${ }^{*} p<0.05$ of release in PD versus control by Student's $t$ test. Data shown are mean values \pm SE of four controls and six PD cases, each done in triplicate.

of acridine orange taken up into putamen vesicle preparations which reflects ATP-dependent proton uptake into vesicles. There was no difference between controls and PD, neither for the ATPinduced acidification (decrease of fluorescence after the ATPaddition at $60 \mathrm{~ms}$ ), nor for the breakdown of acidity induced by carbonyl cyanide FCCP (increase of fluorescence after the addition of the ionophore at $300 \mathrm{~ms}$; Fig. 5).

\section{Discussion}

To our knowledge, experiments on the functional state of the VMAT2 in synaptic vesicles isolated from autopsied human brain tissue, have never been reported previously. Here, we present direct evidence for an impaired vesicular uptake of DA in the striatum of patients with PD. Our results indicate a compromised capability to sequester DA within the striatal DAergic nerve terminals in this disorder. 

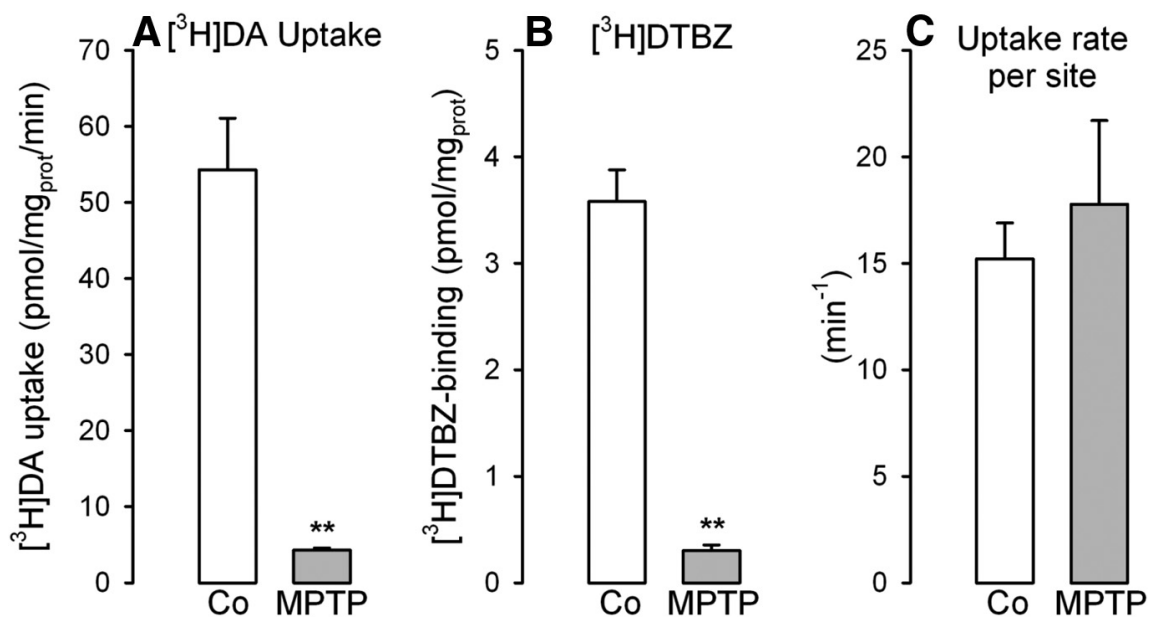

Figure 4. Synaptic vesicles prepared from putamen of MPTP monkeys and controls. A, Specific DA uptake. Synaptic vesicle preparations ( $25 \pm 3$ and $26 \pm 2 \mu \mathrm{g}$ protein for controls and MPTP, respectively) were incubated in the absence or presence of 1 $\mu \mathrm{m}$ reserpine with $0.1 \mu \mathrm{M}\left[{ }^{3} \mathrm{H}\right] \mathrm{DA}$ at $30^{\circ} \mathrm{C}$ for $4 \mathrm{~min} ;{ }^{* *} p<0.00001$ specific uptake in MPTP versus control by Student's $t$ test. $\boldsymbol{B}$, DTBZ-binding. Synaptic vesicle preparations ( $16 \pm 2$ and $16 \pm 1 \mu \mathrm{g}$ protein for controls and MPTP, respectively) were incubated in the absence or presence of $1 \mu \mathrm{m}$ tetrabenazine with $4 \mathrm{~nm}\left[{ }^{3} \mathrm{H}\right] \mathrm{DTBZ}$ at $30^{\circ} \mathrm{C}$ for $90 \mathrm{~min} ;{ }^{* *} \mathrm{p}<0.00001$ specific binding in MPTP versus control by Student's $t$ test. C, Uptake per DTBZ-binding site. For each synaptic vesicle preparation, specific DA uptake was divided by specific DTBZ-binding. Data shown are mean values \pm SE of eight control and seven MPTP monkeys, each done in triplicate.

Compared with controls, in PD the uptake rate of DA per vesicular monoamine transport site was reduced both in caudate and putamen by 53 and 55\%, respectively; calculated per vesicular DA transport site proper the loss was 56\% in caudate and $90 \%$ in putamen. The magnitude of striatal VMAT2 function loss appears functionally highly relevant. VMAT2 transgenic mouse lines expressing $\sim 5-10 \%$ of normal VMAT2 have been recently shown to develop, in addition to severe striatal DA loss, a DA dysfunction with indices of oxidative stress, (retrograde) nigrostriatal DA neurodegeneration and behavioral features of PD sensitive to L-DOPA (Caudle et al., 2007). Thus, it appears that VMAT2 deficiency alone can initiate brain changes similar to what characterize PD. Also, recently a mutation in the VMAT2 gene has been found in children of an extended consanguineous family with parkinsonism as the clinically leading phenotype sensitive to DA agonist treatment (Rilstone et al., 2013). In any case, the DA transport defect in our patients does appear to be a feature of PD, being neither an aspect of the great variability of normal VMAT2 protein expression nor due to some, as yet unknown alteration of vesicular transport activity in PD nerve terminals "thinned out" by the neurodegenerative process. Thus, comparable degree of degeneration of nigrostriatal (putamen) DAergic terminals produced by MPTP in our cynomolgus monkeys did not reduce the uptake of DA per vesicular transport site.

Human versus monkey control postmortem striatal tissue

Absolute amounts of DA taken up in vesicular preparations of putamen were more than 10-fold higher in control monkeys than human controls. This could be due to species differences or different time intervals between death and freezing of the brain, 5-10 min for monkeys versus 5-20 h for humans. There was no difference of postmortem interval between parkinsonian and control brains, neither in humans nor in monkeys ruling out any bias for comparisons PD/MPTP subjects and the respective controls. Absolute striatal DA and HVA tissue levels were also higher in monkeys than in humans; the quite similar HVA/DA ratios of human and monkey controls, however, point to a true species difference and therefore comparability of these DAergic parameters between humans and monkeys.

Retention of DA in monoamine vesicles The reduced uptake per monoamine transport site in PD could result from reduced vesicular retention of DA within the 4 min incubation time of the uptake assay. However, we found no indication for a leakage of the vesicular membrane, with the time-dependent loss of DA from preloaded and washed vesicles being the same between PD and controls; also the ionophore nigericin did not reduce DA retention to a greater extent in $\mathrm{PD}$ than in control samples. In fact, efflux of DA was slightly, but significantly attenuated from preloaded PD vesicles as compared with controls; however, the much lower efflux than uptake rates annul any compensation by the reduced efflux of a potential increase of cytosolic DA consequent to reduced uptake rates. Furthermore, residual endogenous DA in vesicular preparations from PD putamen were actually (not significantly) lower than from controls which rules out retained DA as a mechanism of reducing in vitro uptake specifically in PD.

\section{Proton gradient in striatal vesicle preparations}

Impaired transport of DA into synaptic vesicles can result from a change of the transporter protein VMAT2 or a reduced proton gradient provided by the $\mathrm{H}^{+}$-ATPase. Acidification as measured by ATP-dependent quenching of acridine fluorescence was not different between vesicular preparations from PD and control putamen, nor was the abolishment by the protonophore FCCP. Therefore, we have no indication for a dissipating effect on the $\mathrm{pH}$ gradient in PD synaptic vesicles.

\section{Maximal velocity versus affinity}

The reduced DA uptake per monoamine transport site in PD could be due either to reduced maximal uptake velocity of VMAT2 or reduced affinity for the substrate DA. This could be resolved by doing complete uptake-concentration curves in each PD and control case; however, this was not possible due to the limited amounts of striatal tissue available. A distinction between reduction of maximal velocity versus reduced affinity to DA is interesting from a mechanistic point of view. On the functional level, however, both mechanisms would reduce DA clearance from the cytosol, considering that cytosolic DA concentrations are far below the $K_{M}$ of vesicular uptake (Mosharov et al., 2009).

\section{Relevance to the ethiopathogenesis of $P D$}

Inhibition or downregulation of the DA sequestering function of VMAT2 was recently directly shown to increase cytosolic catechol/DA concentrations (Mosharov et al., 2003, 2009; Vergo et al., 2007), and in vivo accumulation of cytosolic DA alone proved sufficient to trigger oxidative stress and neurodegeneration (Chen et al., 2008). Granting that our observations reflect the situation in vivo, they can be taken as indicating increased cytosolic DA levels in PD striatum in vivo, an abnormality possibly already established in the preclinical phase of the disease (see below). This in turn could lower the threshold for several path- 
ways of striatal DAergic neurodegeneration in patients. Our inability to obtain autopsied brains of patients in the presymptomatic phase of PD is an obvious limitation imposed on our study.

In addition to VMAT2 dysfunction, other proposed mechanisms of DA neuronal death (complex I inhibition; mitochondrial failure, misfolded proteins) increase intracellular oxidant stress (Jenner, 1998; Tabner et al., 2002; Dauer and Przedborski, 2003; Hauser and Hastings, 2013) thereby potentially damaging the VMAT2 protein (Eyerman and Yamamoto, 2007; Watabe and Nakaki, 2008) or the V-type $\mathrm{H}^{+}$-ATPase proton pump (Terland et al., 2006). However, the vesicular DA uptake per transport site was quite unaffected in our MPTP parkinsonian monkeys despite the fact that striatal oxidative stress is well established in MPTP treated animals, with superoxide and nitric oxide participating in the neurotoxic process (Przedborski et al., 2000). Oxidative VMAT2 damage would also be expected consequent to administration of L-DOPA which has been shown to increase free cytosolic DA in ventral midbrain DA neurons of mice in ex vivo experiments (Mosharov et al., 2009). There is, however, no clinical evidence for L-DOPA being detrimental to the progression of $\mathrm{PD}$ symptoms (Parkinson Study Group, 2004), and also in our L-DOPA treated patients no correlation was detectable between time of last L-DOPA dose before death and VMAT2 transport dysfunction. Together caution in drawing far-reaching conclusions about clinical and/or causative relevance of the available experimental data appears in order.

What then could have been the primary event reducing vesicular striatal DA uptake per VMAT2 transport site in our patients? Of the environmental neurotoxicants of industrial and natural origin affecting brain VMAT2 or DA neuron integrity (Betarbet et al., 2000; Fonnum and Mariussen, 2009; Inamdar et al., 2013), some organochlorine compounds have been detected in PD brains (Corrigan et al., 2000) suggesting possible environmental impact on severity or progression of the disease. Nonetheless, PD is not a disease of the modern industrial era (Parkinson, 1817); therefore, genetic factors predisposing to PD are most conspicuous. Although functional mutations in the coding region of SLC18A2 (VMAT2) have not been detected in patients with idiopathic PD (Glatt et al., 2006), two recent genome-wide association studies found increased susceptibility to idiopathic PD in common variants of the $\alpha$-synuclein gene (Satake et al., 2009; Simon-Sanchez et al., 2009). Indeed, a modulation of VMAT2 protein expression by mutant or wildtype human $\alpha$-synuclein was reported in several studies (Lotharius and Brundin, 2002; Lotharius et al., 2002; Guo et al., 2008) and lowering synuclein levels in human DAergic neuro-

B
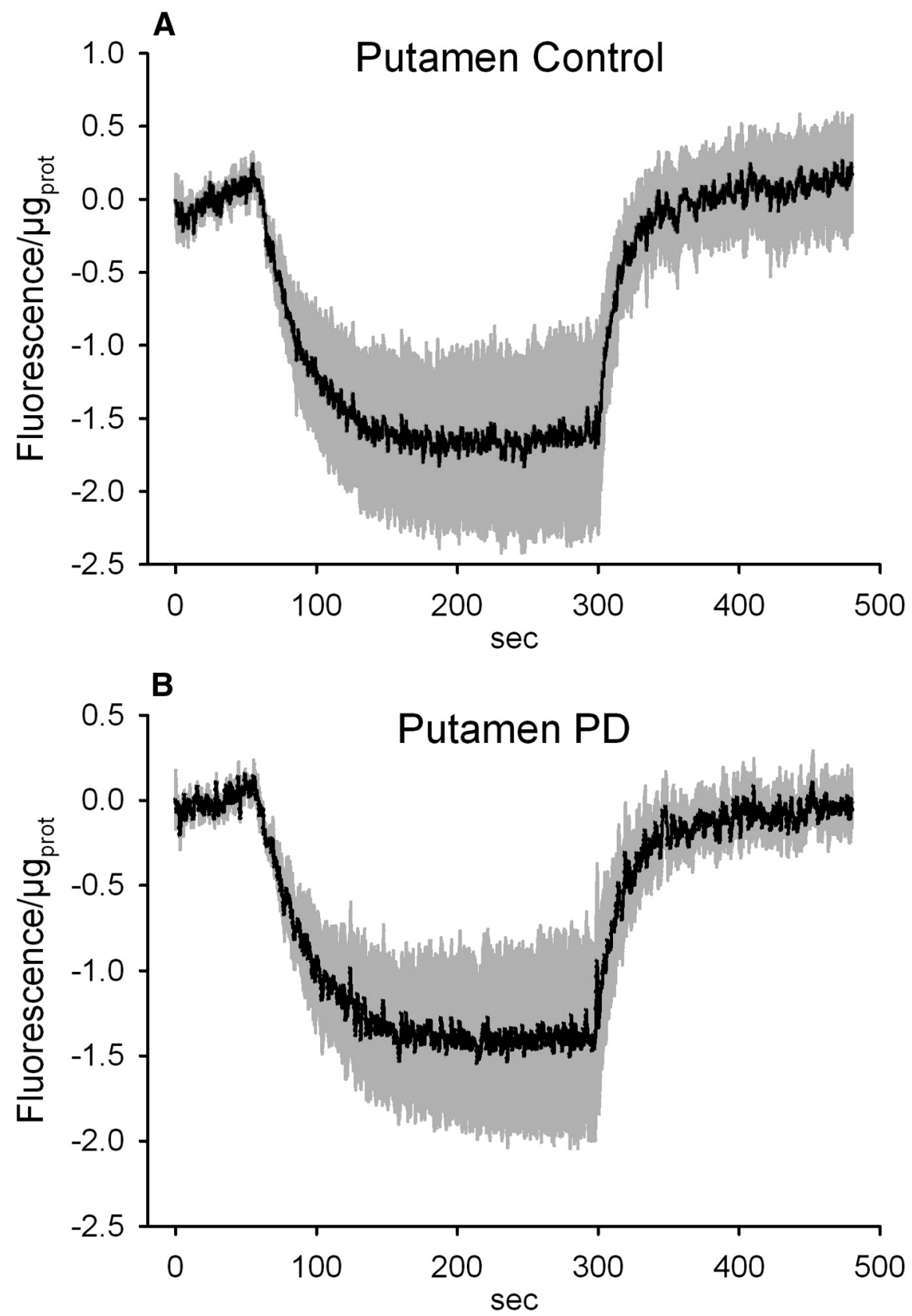

Figure 5. Proton gradient measurement on synaptic vesicles prepared from putamen of patients with PD and controls. Synaptic vesicle preparations ( $47 \pm 4$ and $48 \pm 7 \mu \mathrm{g}$ protein for controls and $\mathrm{PD}$, respectively) were incubated with $2 \mu \mathrm{m}$ acridine orange and acidification was measured by quenching of fluorescence at $493 \mathrm{~nm}$ (excitation) and $530 \mathrm{~nm}$ (emission) after addition of 0.5 mM MgATP at $60 \mathrm{~s}$ and proton gradient abolition by addition of $1 \mu \mathrm{m}$ carbonyl cyanide FCCP at $300 \mathrm{~s}$. Shown are mean values of fluorescent traces shifted to 0 fluorescence at the time interval $0-58 \mathrm{~s} \pm$ SE (gray area) of four controls $(\boldsymbol{A})$ and six PD patients $(\boldsymbol{B})$.

blastoma cells increased total VMAT2 particle density and number of VMAT2 particles per vesicle (Fountaine et al., 2008). However, the above alterations would not necessarily result in our finding of reduced DA uptake per monoamine transport site. Significantly, elevated $\alpha$-synuclein levels were recently found in individual surviving neurons of idiopathic PD substantia nigra (Gründemann et al., 2008), in principle permitting increased vesicular $\alpha$-synuclein-VMAT2 interactions which had been detected in yeast-two hybrid or GST pull-down experiments (Dean et al., 2007; Guo et al., 2008). Furthermore, $\alpha$-synuclein-VMAT2 complexes have been detected in normal human striatum (Guo et al., 2008) and $\alpha$-synuclein-VMAT2 aggregates in (swollen) dys- 
trophic striatal DA axons and terminals in the AAV- $\alpha$-synuclein rat model of nigrostriatal neurodegeneration (Lundblad et al., 2012). Collectively, these observations allow for the occurrence of $\alpha$-synuclein-VMAT2 interactions with increased formation of striatal $\alpha$-synuclein-VMAT2 complexes in DA neurons, which might account for our specific finding of reduced vesicular DA uptake per striatal VMAT2 transport site. Previous studies have shown that VMAT2 function decisively regulates synaptic DA release by affecting its quantal size (Fon et al., 1997; Pothos et al., 2000), and both moderate reductions of VMAT2 in heterozygous knock-out mice (Fon et al., 1997; Wang et al., 1997), and overexpression of $\alpha$-synuclein (Gaugler et al., 2012; Lundblad et al., 2012; Janezic, 2013) impaired synaptic DA release well before neuronal degeneration. Considering that VMAT2 and $\alpha$-synuclein are essentially expressed at the presynaptic level, our findings suggest that in PD the initial events start, likely in the preclinical phase, at synaptic terminals rather than in soma. This might have important therapeutic implications aiming to halt neurodegeneration of the nigro-striatal system.

In conclusion, we report for the first time a defect in the vesicular DA transport machinery in synaptic vesicles isolated from the striatum of patients with PD. The impairment of the vesicular DA uptake appears to be localized at the VMAT2 protein itself, either in as yet unknown posttranslational modifications, or more likely, VMAT2-interacting molecules. We propose that this VMAT2 defect may be an early abnormality promoting several neurodegenerative pathways ultimately leading to progressive loss of nigro-striatal DAergic neurons in PD.

\section{References}

Betarbet R, Sherer TB, MacKenzie G, Garcia-Osuna M, Panov AV, Greenamyre JT (2000) Chronic systemic pesticide exposure reproduces features of Parkinson's disease. Nat Neurosci 3:1301-1306. CrossRef Medline

Bilska A, Dubiel M, Sokołowska-Jezewicz M, Lorenc-Koci E, Włodek L (2007) Alpha-lipoic acid differently affects the reserpine-induced oxidative stress in the striatum and prefrontal cortex of rat brain. Neuroscience 146:1758-1771. CrossRef Medline

Blesa J, Pifl C, Sánchez-González MA, Juri C, García-Cabezas MA, Adanez R, Iglesias E, Collantes M, Peñuelas I, Sánchez-Hernández JJ, RodríguezOroz MC, Avendaño C, Hornykiewicz O, Cavada C, Obeso JA (2012) The nigrostriatal system in the presymptomatic and symptomatic stages in the MPTP monkey model: a PET, histological and biochemical study. Neurobiol Dis 48:79-91. CrossRef Medline

Caudle WM, Richardson JR, Wang MZ, Taylor TN, Guillot TS, McCormack AL, Colebrooke RE, Di Monte DA, Emson PC, Miller GW (2007) Reduced vesicular storage of dopamine causes progressive nigrostriatal neurodegeneration. J Neurosci 27:8138-8148. CrossRef Medline

Caudle WM, Colebrooke RE, Emson PC, Miller GW (2008) Altered vesicular dopamine storage in Parkinson's disease: a premature demise. Trends Neurosci 31:303-308. CrossRef Medline

Chen L, Ding Y, Cagniard B, Van Laar AD, Mortimer A, Chi W, Hastings TG, Kang UJ, Zhuang X (2008) Unregulated cytosolic dopamine causes neurodegeneration associated with oxidative stress in mice. J Neurosci 28: 425-433. CrossRef Medline

Colliver TL, Pyott SJ, Achalabun M, Ewing AG (2000) VMAT-mediated changes in quantal size and vesicular volume. J Neurosci 20:5276-5282. Medline

Corrigan FM, Wienburg CL, Shore RF, Daniel SE, Mann D (2000) Organochlorine insecticides in substantia nigra in Parkinson's disease. J Toxicol Environ Health A 59:229-234. CrossRef Medline

Dauer W, Przedborski S (2003) Parkinson's disease: mechanisms and models. Neuron 39:889-909. CrossRef Medline

Dean ED, Torres GE, Miller GW (2007) Alpha-synuclein interacts with VMAT2 to regulate VMAT2 activity. Toxicol Sci 96:45.

Edwards RH (1993) Neural degeneration and the transport of neurotransmitters. Ann Neurol 34:638-645. CrossRef Medline
Ehringer H, Hornykiewicz O (1960) Distribution of noradrenaline and dopamine (3-hydroxytyramine) in the human brain and their behavior in diseases of the extrapyramidal system (in German). Klin Wochenschr 38:1236-1239. CrossRef Medline

Erickson JD, Masserano JM, Barnes EM, Ruth JA, Weiner N (1990) Chloride ion increases $\left[{ }^{3} \mathrm{H}\right]$ dopamine accumulation by synaptic vesicles purified from rat striatum: inhibition by thiocyanate ion. Brain Res 516:155-160. CrossRef Medline

Eyerman DJ, Yamamoto BK (2007) A rapid oxidation and persistent decrease in the vesicular monoamine transporter 2 after methamphetamine. J Neurochem 103:1219-1227. CrossRef Medline

Fon EA, Pothos EN, Sun BC, Killeen N, Sulzer D, Edwards RH (1997) Vesicular transport regulates monoamine storage and release but is not essential for amphetamine action. Neuron 19:1271-1283. CrossRef Medline

Fonnum F, Mariussen E (2009) Mechanisms involved in the neurotoxic effects of environmental toxicants such as polychlorinated biphenyls and brominated flame retardants. J Neurochem 111:1327-1347. CrossRef Medline

Fornstedt B, Carlsson A (1989) A marked rise in 5-S-cysteinyl-dopamine levels in guinea-pig striatum following reserpine treatment. J Neural Transm 76:155-161. CrossRef Medline

Fountaine TM, Venda LL, Warrick N, Christian HC, Brundin P, Channon KM, Wade-Martins R (2008) The effect of alpha-synuclein knockdown on MPP + toxicity in models of human neurons. Eur J Neurosci 28:24592473. CrossRef Medline

Fuentes P, Paris I, Nassif M, Caviedes P, Segura-Aguilar J (2007) Inhibition of VMAT-2 and DT-diaphorase induce cell death in a substantia nigraderived cell line-an experimental cell model for dopamine toxicity studies. Chem Res Toxicol 20:776-783. CrossRef Medline

Gaugler MN, Genc O, Bobela W, Mohanna S, Ardah MT, El-Agnaf OM, Cantoni M, Bensadoun JC, Schneggenburger R, Knott GW, Aebischer P, Schneider BL (2012) Nigrostriatal overabundance of alpha-synuclein leads to decreased vesicle density and deficits in dopamine release that correlate with reduced motor activity. Acta Neuropathol 123:653-669. CrossRef Medline

Gibb WR, Lees AJ (1991) Anatomy, pigmentation, ventral and dorsal subpopulations of the substantia nigra, and differential cell death in Parkinson's disease. J Neurol Neurosurg Psychiatry 54:388-396. CrossRef Medline

Glatt C, Almonte M, Taylor T, Edwards RH, Freimer N, Tanner C (2006) Structural variants in the vesicular monoamine transporter do not contribute to sporadic Parkinson's disease. Mov Disord 21:426-427. CrossRef Medline

Goldstein DS, Sullivan P, Holmes C, Miller GW, Alter S, Strong R, Mash DC, Kopin IJ, Sharabi Y (2013) Determinants of buildup of the toxic dopamine metabolite DOPAL in Parkinson's disease. J Neurochem 126:591603. CrossRef Medline

Graham DG, Tiffany SM, Bell WR Jr, Gutknecht WF (1978) Autoxidation versus covalent binding of quinones as the mechanism of toxicity of dopamine, 6-hydroxydopamine, and related compounds toward C1300 neuroblastoma cells in vitro. Mol Pharmacol 14:644-653. Medline

Greenfield JG, Bosanquet FD (1953) The brain-stem lesions in Parkinsonism. J Neurol Neurosurg Psychiatry 16:213-226. CrossRef Medline

Gründemann J, Schlaudraff F, Haeckel O, Liss B (2008) Elevated alphasynuclein mRNA levels in individual UV-laser-microdissected dopaminergic substantia nigra neurons in idiopathic Parkinson's disease. Nucleic Acids Res 36:e38. CrossRef Medline

Guillot TS, Miller GW (2009) Protective actions of the vesicular monoamine transporter 2 (VMAT2) in monoaminergic neurons. Mol Neurobiol 39:149-170. CrossRef Medline

Guo JT, Chen AQ, Kong Q, Zhu H, Ma CM, Qin C (2008) Inhibition of vesicular monoamine transporter-2 activity in alpha-synuclein stably transfected SH-SY5Y cells. Cell Mol Neurobiol 28:35-47. CrossRef Medline

Hassler R (1938) The pathology of paralysis agitans and post-encephalitic Parkinson's. J für Psychologie und Neurologie 48:387-426.

Hastings TG, Lewis DA, Zigmond MJ (1996) Role of oxidation in the neurotoxic effects of intrastriatal dopamine injections. Proc Natl Acad Sci U S A 93:1956-1961. CrossRef Medline

Hauser DN, Hastings TG (2013) Mitochondrial dysfunction and oxidative 
stress in Parkinson's disease and monogenic parkinsonism. Neurobiol Dis 51:35-42. CrossRef Medline

Hornykiewicz O (1963) The tropical localization and content of noradrenalin and dopamine (3-hydroxytyramine) in the substantia nigra of normal persons and patients with Parkinson's disease (in German). Wien Klin Wochenschr 75:309-312. Medline

Hornykiewicz O (1964) The role of brain dopamine (3-hydroxytyramine) in parkinsonism. In: Biochemical and neurophysiological correlations of centrally acting drugs (Trabucchi E, Paoletti R, Canal N, eds), pp 57-68. Pergamon, Oxford.

Hornykiewicz O (1998) Biochemical aspects of Parkinson's disease. Neurology 51:S2-S9. CrossRef Medline

Imperato A, Di Chiara G (1984) Trans-striatal dialysis coupled to reverse phase high performance liquid chromatography with electrochemical detection: a new method for the study of the in vivo release of endogenous dopamine and metabolites. J Neurosci 4:966-977. Medline

Inamdar AA, Hossain MM, Bernstein AI, Miller GW, Richardson JR, Bennett JW (2013) Fungal-derived semiochemical 1-octen-3-ol disrupts dopamine packaging and causes neurodegeneration. Proc Natl Acad Sci U S A 110:19561-19566. CrossRef Medline

Janezic S, Threlfell S, Dodson PD, Dowie MJ, Taylor TN, Potgieter D, Parkkinen L, Senior SL, Anwar S, Ryan B, Deltheil T, Kosillo P, Cioroch M, Wagner K, Ansorge O, Bannerman DM, Bolam JP, Magill PJ, Cragg SJ, Wade-Martins R (2013) Deficits in dopaminergic transmission precede neuron loss and dysfunction in a new Parkinson model. Proc Natl Acad Sci U S A 110:E4016-E4025. CrossRef Medline

Jenner P (1998) Oxidative mechanisms in nigral cell death in Parkinson's disease. Mov Disord 13:24-34. Medline

Lotharius J, Brundin P (2002) Impaired dopamine storage resulting from alpha-synuclein mutations may contribute to the pathogenesis of Parkinson's disease. Hum Mol Genet 11:2395-2407. CrossRef Medline

Lotharius J, Barg S, Wiekop P, Lundberg C, Raymon HK, Brundin P (2002) Effect of mutant alpha-synuclein on dopamine homeostasis in a new human mesencephalic cell line. J Biol Chem 277:38884-38894. CrossRef Medline

Lundblad M, Decressac M, Mattsson B, Björklund A (2012) Impaired neurotransmission caused by overexpression of alpha-synuclein in nigral dopamine neurons. Proc Natl Acad Sci U S A 109:3213-3219. CrossRef Medline

Millar J, Stamford JA, Kruk ZL, Wightman RM (1985) Electrochemical, pharmacological and electrophysiological evidence of rapid dopamine release and removal in the rat caudate nucleus following electrical stimulation of the median forebrain bundle. Eur J Pharmacol 109:341-348. CrossRef Medline

Miller GW, Gainetdinov RR, Levey AI, Caron MG (1999) Dopamine transporters and neuronal injury. Trends Pharmacol Sci 20:424-429. CrossRef Medline

Moriyama Y, Futai M (1990) H(+)-ATPase, a primary pump for accumulation of neurotransmitters, is a major constituent of brain synaptic vesicles. Biochem Biophys Res Commun 173:443-448. CrossRef Medline

Mosharov EV, Gong LW, Khanna B, Sulzer D, Lindau M (2003) Intracellular patch electrochemistry: regulation of cytosolic catecholamines in chromaffin cells. J Neurosci 23:5835-5845. Medline

Mosharov EV, Larsen KE, Kanter E, Phillips KA, Wilson K, Schmitz Y, Krantz DE, Kobayashi K, Edwards RH, Sulzer D (2009) Interplay between cytosolic dopamine, calcium, and alpha-synuclein causes selective death of substantia nigra neurons. Neuron 62:218-229. CrossRef Medline

Nelson N, Cidon S, Moriyama Y (1988) Chromaffin granule proton pump. Methods Enzymol 157:619-633. CrossRef Medline

Parkinson J (1817) An essay on the shaking palsy. London: Sherwood, Neely, and Jones.

Parkinson Study Group (2004) Levodopa and the progression of Parkinson's disease. N Engl J Med 351:2498-2508. CrossRef Medline

Philippu A, Beyer J (1973) Dopamine and noradrenaline transport into subcellular vesicles of the striatum. Naunyn Schmiedebergs Arch Pharmacol 278:387-402. CrossRef Medline

Pothos EN, Larsen KE, Krantz DE, Liu Y, Haycock JW, Setlik W, Gershon MD, Edwards RH, Sulzer D (2000) Synaptic vesicle transporter expres- sion regulates vesicle phenotype and quantal size. J Neurosci 20:72977306. Medline

Przedborski S, Jackson-Lewis V, Djaldetti R, Liberatore G, Vila M, Vukosavic S, Almer G (2000) The parkinsonian toxin MPTP: action and mechanism. Restor Neurol Neurosci 16:135-142. Medline

Rilstone JJ, Alkhater RA, Minassian BA (2013) Brain dopamine-serotonin vesicular transport disease and its treatment. N Engl J Med 368:543-550. CrossRef Medline

Satake W, Nakabayashi Y, Mizuta I, Hirota Y, Ito C, Kubo M, Kawaguchi T, Tsunoda T, Watanabe M, Takeda A, Tomiyama H, Nakashima K, Hasegawa K, Obata F, Yoshikawa T, Kawakami H, Sakoda S, Yamamoto M, Hattori N, Murata M, et al. (2009) Genome-wide association study identifies common variants at four loci as genetic risk factors for Parkinson's disease. Nat Genet 41:1303-1307. CrossRef Medline

Satou T, Anderson AJ, Itoh T, Tamai Y, Hayashi Y, Hashimoto S (2001) Repetitive administration of tetrabenazine induces irreversible changes in locomotion and morphology of the substantia nigra in rats. Exp Toxicol Pathol 53:303-308. CrossRef Medline

Seidler FJ, Kirksey DF, Lau C, Whitmore WL, Slotkin TA (1977) Uptake of $(-){ }^{3} \mathrm{H}$-norepinephrine by storage vesicles prepared from whole rat brain: properties of the uptake system and its inhibition by drugs. Life Sci 21:1075-1085. CrossRef Medline

Simon-Sanchez J, Schulte C, Bras JM, Sharma M, Gibbs JR, Berg D, PaisanRuiz C, Lichtner P, Scholz SW, Hernandez DG, Krüger R, Federoff M, Klein C, Goate A, Perlmutter J, Bonin M, Nalls MA, Illig T, Gieger C, Houlden $\mathrm{H}$, et al. (2009) Genome-wide association study reveals genetic risk underlying Parkinson's disease. Nat Genet 41:1308-1312. CrossRef Medline

Spencer JP, Jenner P, Daniel SE, Lees AJ, Marsden DC, Halliwell B (1998) Conjugates of catecholamines with cysteine and GSH in Parkinson's disease: possible mechanisms of formation involving reactive oxygen species. J Neurochem 71:2112-2122. CrossRef Medline

Spina MB, Cohen G (1989) Dopamine turnover and glutathione oxidation: implications for Parkinson disease. Proc Natl Acad Sci U S A 86:13981400. CrossRef Medline

Tabner BJ, Turnbull S, El-Agnaf OM, Allsop D (2002) Formation of hydrogen peroxide and hydroxyl radicals from Abeta and alpha-synuclein as a possible mechanism of cell death in Alzheimer's disease and Parkinson's disease. Free Radic Biol Med 32:1076-1083. CrossRef Medline

Terland O, Almås B, Flatmark T, Andersson KK, Sørlie M (2006) Oneelectron oxidation of catecholamines generates free radicals with an in vitro toxicity correlating with their lifetime. Free Radic Biol Med 41: 1266-1271. CrossRef Medline

Uhl GR, Li S, Takahashi N, Itokawa K, Lin Z, Hazama M, Sora I (2000) The VMAT2 gene in mice and humans: amphetamine responses, locomotion, cardiac arrhythmias, aging, and vulnerability to dopaminergic toxins. FASEB J 14:2459-2465. CrossRef Medline

Vergo S, Johansen JL, Leist M, Lotharius J (2007) Vesicular monoamine transporter 2 regulates the sensitivity of rat dopaminergic neurons to disturbed cytosolic dopamine levels. Brain Res 1185:18-32. CrossRef Medline

Wang YM, Gainetdinov RR, Fumagalli F, Xu F, Jones SR, Bock CB, Miller GW, Wightman RM, Caron MG (1997) Knockout of the vesicular monoamine transporter 2 gene results in neonatal death and supersensitivity to cocaine and amphetamine. Neuron 19:1285-1296. CrossRef Medline

Watabe M, Nakaki T (2008) Mitochondrial complex I inhibitor rotenone inhibits and redistributes vesicular monoamine transporter 2 via nitration in human dopaminergic SH-SY5Y cells. Mol Pharmacol 74:933-940. CrossRef Medline

Whittaker VP, Michaelson IA, Kirkland RJ (1964) The separation of synaptic vesicles from nerve-ending particles ("synaptosomes"). Biochem J 90: 293-303. Medline

Wilson JM, Levey AI, Rajput A, Ang L, Guttman M, Shannak K, Niznik HB, Hornykiewicz O, Pifl C, Kish SJ (1996) Differential changes in neurochemical markers of striatal dopamine nerve terminals in idiopathic Parkinson's disease. Neurology 47:718-726. CrossRef Medline 